\title{
Student Engagement and Student Learning: Testing the Linkages
}

\author{
Robert M. Carini \\ Assistant Professor \\ Department of Sociology \\ University of Louisville
}

George D. Kuh

Chancellor's Professor and Director

Center for Postsecondary Research

Indiana University Bloomington

Stephen P. Klein

Senior Research Scientist

The RAND Corporation

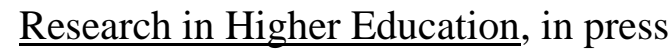

A version of this paper was presented at the annual meeting of the American Educational Research Association, San Diego, April 2004. We thank Chelle Carini, Pamela Eddy, and a trio of anonymous reviewers for their comments on earlier drafts. Direct correspondence to Robert Carini, Department of Sociology, University of Louisville, 103 Lutz Hall, Louisville, KY 40292. Telephone: 502-852-8030, Fax: 502-852-0099, e-mail: rmcari01@louisville.edu. 


\title{
Student Engagement and Student Learning: Testing the Linkages
}

\begin{abstract}
This study examines (1) the extent to which student engagement is associated with experimental and traditional measures of academic performance, (2) whether the relationships between engagement and academic performance are conditional, and (3) whether institutions differ in terms of their ability to convert student engagement into academic performance. The sample consisted of 1,058 students at 14 four-year colleges and universities that completed several instruments during 2002. Many measures of student engagement were linked positively with such desirable learning outcomes as critical thinking and grades, although most of the relationships were weak in strength. The results suggest that the lowest-ability students benefit more from engagement than classmates, first-year students and seniors convert different forms of engagement into academic achievement, and certain institutions more effectively convert student engagement into higher performance on critical thinking tests.
\end{abstract}

KEY WORDS: student engagement, critical thinking, value added, NSSE, student learning 


\section{Student Engagement and Student Learning: How Can We Characterize the Linkages? \\ Background}

Various approaches have been used to estimate collegiate quality. For instance, some analyses focus on quantitative characteristics of institutions and programs, such as graduation rates, minority access, and faculty characteristics. Other approaches emphasize outcomes such as performance on general education and major field tests, expert judgments by accreditors (which are usually based usually on inputs and resources), and reputational ratings such as those published by US News \& World Report. Still others employ surveys of student experiences and self-reports of their learning and personal development. Each method has advantages and limitations as well as champions and critics (Chun, 2002; Klein, 2001, 2002; Kuh \& Pascarella, 2004; Pascarella, 2001).

Comprehensive assessment systems typically use multiple indicators to tap quality (Astin, 1991; Ewell, 1984, 1988; Gentemann, Fletcher, \& Potter, 1994; Halpern, 1987; Jacobi, Astin, \& Ayala, 1987; Ratcliff, Jones et al., 1997; Terenzini, 1989; Vandament, 1987). Student surveys are particularly popular because they are generally less expensive and easier to develop and administer than tests of student knowledge and proficiencies. When well-crafted, student surveys can provide insights into the student experience that other sources of information cannot, such as estimates of one's ability to interact effectively with others on an individual basis or in small groups, and the degree to which one’s values and ethics have developed since starting college (Kuh, 2001, 2003; Pace, 1984).

A fair amount of evidence indicates that student self-reports are valid and reliable under certain conditions (Baird, 1976; Pace, 1984; Pohlmann, 1974): (1) the information requested is known to the respondents, (2) the questions are phrased clearly and unambiguously, (3) the 
questions refer to recent activities, (4) the respondents think the questions merit a thoughtful response, (5) the information requested is potentially verifiable, and (6) the question asks for information that is known to those answering the questions and does not threaten, embarrass, or violate their privacy or encourage the respondent to respond in socially desirable ways. However, even when surveys are designed to meet these conditions, as with the National Survey of Student Engagement (NSSE) (Kuh et al., 2001), it does not necessarily mean that the surveys ask about behaviors that are linked to desired outcomes, such as whether institutions that engage students at higher levels are adding value to the student experience.

Student engagement is generally considered to be among the better predictors of learning and personal development. The premise is deceptively simple, perhaps self-evident: The more students study or practice a subject, the more they tend to learn about it. Likewise, the more students practice and get feedback on their writing, analyzing, or problem solving, the more adept they should become (Kuh, 2003). The very act of being engaged also adds to the foundation of skills and dispositions that is essential to live a productive and satisfying life after college. That is, students who are involved in educationally productive activities in college are developing habits of the mind and heart that enlarge their capacity for continuous learning and personal development (Shulman, 2002). The widespread use of the NSSE survey - more than 850 different four-year colleges have used it at least once since 2000 - underscores the need to understand the degree to which - and the processes whereby - student engagement contributes to more favorable outcomes for college students.

In one recent study, using data from six South Dakota public colleges and universities, the National Center for Higher Education Management Systems (NCHEMS) found some positive links between student engagement and ACT CAAP scores, though the strength of the 
statistically significant associations were modest at best (Ewell, 2002). However, the NCHEMS researchers emphasized that the measures of student engagement and the CAAP test scores were obtained at different points in time, in many instances a year or more separated the two measurement points. Other studies are more promising, such as those by Hughes and Pace (2003) and by institutional researchers at individual colleges and universities (e.g., Indiana University Bloomington, St. Xavier University, University of Montana, and the University of Wisconsin-Green Bay) who report positive relationships between NSSE results and persistence, as well as academic performance represented by college grade point average (GPA). Even so, questions remain about whether collegiate grades and tests such as the ACT CAAP are adequate measures of how much students learn, and to what degree the institution or general intellectual ability shapes GPA.

To address these questions, RAND and the Council for the Aid to Education are developing, testing and refining new measures of college-level learning. The goal is to provide richer indicators of important dimensions of student learning than are tapped by existing instruments (Klein, 2002; Klein et al., in press). By adjusting for student ability prior to matriculation (such as through SAT scores and background characteristics), it is anticipated that the new RAND measures will be more sensitive to program and institutional effects than traditional tests of general educational abilities (Bohr et al., 1994; Pascarella et al., 1994; Pascarella \& Terenzini, 1991; Winter, McClelland \& Stewart, 1981), thereby promising valueadded estimates of institutional performance (Benjamin \& Hersh, 2002). 


\section{Purposes}

This study examines the forms of student engagement associated with learning as measured by the RAND tests, the new essay prompts on the Graduate Record Examination (GRE), and college GPA. More specifically, we sought to determine:

(1) the extent to which student engagement is related to experimental and traditional measures of academic performance;

(2) the forms of student engagement that are most closely related to student performance;

(3) whether the relationships between student engagement and academic performance are "conditional," or vary depending on student characteristics; and

(4) whether certain four-year colleges and universities are more effective than others in converting student engagement into stronger academic performance.

\section{Analytic Approach}

\section{$\underline{\text { Data Sources }}$}

The NSSE survey instrument, The College Student Report (hereafter, The Report), is composed of about 70 items that assess the extent to which students devote time and energy to educationally purposeful activities. A large majority of items from The Report deal with behaviors that have been linked empirically to favorable outcomes of college in prior studies (Kuh, 2001, 2003). The psychometric properties of the NSSE survey are reported in detail by Kuh et al. (2001) and at http://www.iub.edu/ nsse/html/psychometric_framework_2002.htm. NSSE results have been treated by some postsecondary institutions as a proxy for student learning, although the survey was designed primarily to provide process indicators, or measures that could help colleges and universities identify areas of student performance and institutional practices that could be improved to enhance the overall quality of the student experience (Ewell \& Jones, 1996). 
The measures developed by RAND consist of a series of newly developed cognitive and performance tests (Klein et al., in press). Specifically, the RAND tests consist of various combinations of six different 90-minute critical thinking and performance problems. The two performance tests were modeled after the performance section of the bar exam (Klein, 1996). The four critical thinking tests were derived from "Tasks in Critical Thinking” designed by the

New Jersey Department of Education (Ewell, 1994). Subject areas for the critical thinking tasks included science, social science, and arts and humanities. In addition, RAND researchers administered two essay prompts from the GRE (Klein et al., in press). The 45-minute make-anargument prompt asked students to take and argue a position on a topic. The 30-minute breakan-argument prompt asked students to critically analyze a given position on an issue. The RAND and GRE tasks were presented to students in open-ended formats. In addition, RAND researchers were able to obtain cumulative GPA and total SAT scores for most students in the 2002 field test.

$\underline{\text { Sample and Administration }}$

RAND researchers administered The Report and their own cognitive tests to 1,352 students at 14 four-year colleges and universities during the fall and spring of 2002. Students from all four undergraduate class levels were recruited and paid \$20 to \$25 per hour of testing time as an incentive. SAT scores were not available for 149 students, paring our analytic sample to 1,203 cases. Missing student responses on other control variables reduced the analytic sample further to 1,058 . Of the 1,058 students with complete data, 940 completed the RAND measures and 506 completed the GRE tests. The NSSE instrument was administered in a non-standard method. Instead of exclusively designating a portion of time to administer The Report, students were directed to begin the survey if they completed their open-ended written tasks before time 
was called. They were then given additional time to complete the survey. It is not known what effect, if any, this administration procedure may have had on student responses.

Respondent Characteristics. The colleges that were invited to participate represented an intentional mix of institutional characteristics - public/private, urban/nonurban location, admissions selectivity, region of the country, large/small enrollments, and varied student characteristics such as race/ethnicity. Students at participating institutions self-selected themselves by responding to their university's invitations, such as announcements in student or local newspapers. The four class levels were almost evenly represented (i.e., the sample consisted of 28, 25, 23, and 23 percent first-year students through seniors, respectively). Approximately 98 percent of participants were enrolled full-time, and about 57 percent were women. About 73 percent classified themselves as exclusively White, while 9 percent were Black, seven percent were Asian, three percent were Latina/o, and another 7 percent were multiracial. The percentage of Black respondents was bolstered by the participation of an HBCU institution. Nearly 5 percent of respondents considered themselves international students, and 8 percent had begun college at an institution other than their current one. Full-time students and international students were overrepresented compared with the universe of college students (NSSE, 2003), while transfer students were underrepresented. Ten of 14 colleges (71 percent) were private as compared with 63 percent of U.S. colleges (NSSE, 2004). To the extent that it was possible to do so with 14 colleges, the sample roughly approximated U.S. colleges with respect to region of the country, Carnegie Classification, enrollment, and urbanicity (NSSE, 2004). Klein et al. (in press) provide further details on the characteristics of participating colleges. 


\section{$\underline{\text { Measures }}$}

Student learning was assessed by academic performance as measured by the RAND and GRE test scores, and college-reported GPA. A set of engagement and self-reported outcome measures was selected from the NSSE survey for the analysis. Five of these measures are what NSSE publications have termed “clusters of effective educational practice” - each made up of 6 to 11 related items. The five clusters are: level of academic challenge, active and collaborative learning, student-faculty interaction, enriching educational experiences, and supportive campus environment (Kuh, 2001). A number of other scales more focused on particular engagement areas were also employed: reading and writing, quality of relationships, institutional emphases on good practices, higher-order thinking, student-faculty interaction concerning coursework, and integration of diversity into coursework. Appendix A.1 lists specific survey items that contributed to each scale and provides reliability coefficients. In some instances, there is overlap between items in these scales and the five clusters of effective educational practice (Appendix A.2). We also explored relationships between academic performance measures and self-reported gains associated with attending college in three areas: (1) general education, (2) personal and social development, and (3) practical competence. Finally, we probed the possible link between student engagement and satisfaction with their collegiate experience at their present institution. Descriptions and summary statistics for measures of academic performance, student engagement, and self-reported outcomes are presented in Table 1.

\section{[Insert Table 1 about here]}

\section{Analytic Strategy}

RAND and GRE test scores were standardized by converting each to an SAT metric. The standardization was performed by converting the RAND and GRE scores to distributions that 
had the same mean and standard deviation as the students' SAT scores. To facilitate direct comparisons of GPA across students from different institutions (and to adjust for possible differences in grading standards across institutions), the GPAs within a school were converted to a score distribution that had the same mean and standard deviation as the SAT scores at that school. Once RAND, GRE, and GPA measures were standardized to the SAT scale, we tested the relationships between various student engagement measures and academic performance. We also juxtaposed self-reported gains and satisfaction from the NSSE - what some consider to be meaningful outcomes in their own right (Shulman, 2002) - with measures of student engagement.

We attempted to tease out conditional effects of student engagement on performance by examining these effects for students of different classes, ability levels (as measured by the SAT), sexes, races/ethnicities, fraternity or sorority affiliation, and transfer status, any of which might arguably affect student learning. Searching for conditional effects is important, because it is likely that the impact of college on student learning and personal development will be underestimated if conditional effects are neglected (Pascarella \& Terenzini, 1991, 2005).

In an attempt to parse out precollege academic level, we statistically controlled for students' total SAT score in most analyses. We also controlled for a host of student demographic variables and collegiate experiences that could reasonably influence learning as well as student engagement: class, gender, residence, enrollment status, race/ethnicity, number of parents with a bachelor's degree or higher, major field, amount of unassigned reading, commute time, time spent caring for dependents, and hours worked off campus. We did this to more accurately isolate possible effects of student engagement on "learning" as represented by the RAND, GRE, and GPA measures. 
The literature on student learning is replete with concerns about regression-based analyses to assess change in an outcome over time (Baird, 1988; Cronbach \& Furby, 1970; Pascarella \& Wolniak, 2004; Pike 1992, 2004), especially attempts to attribute changes in a given outcome to a particular experience such as participation in a program or involvement with an organization. In particular, standard approaches to measure change such as gain scores, residual scores, and repeated measures are notoriously unreliable (Baird, 1988; Pike 1992). Many of these so-called "value added" studies rely on the measurement of the outcome at more than one point in time, a minimum of a "pretest” and a "posttest.” With the exception of total SAT score, our data are cross-sectional in nature, in that initial "pretest” measures of RAND, GRE, or GPA at college entrance were not available. In that sense, ours is not a study of changes in student performance over time. However, because we can use total SAT as a control variable, and because SAT is correlated at .48 and .55 with RAND and GRE scores, respectively, we are able to explain substantial portions of the variance on RAND and GRE scores with the SAT score, rendering the unexplained portion to potentially be attributed to the net effect of student engagement. Following the lead of Pike (2004), the central aim of our study is whether students with identical SAT scores (and other student characteristics) but different engagement levels exhibit different learning outcomes. Finally, despite statistically controlling for many student characteristics, this effort - as with all non-experimental research - cannot eliminate the possibility that an unmeasured variable may confound the patterns reported here.

An earlier study using these data reported that students at certain institutions had higher RAND and GRE scores than would be expected given the typical relationship of these scores with their SAT scores (Klein et al., in press). This finding suggests that, relative to other participating institutions, certain colleges added more value than others in our sample. Within 
this study, we consider the possibility that student engagement is a key process by which institutions add value for their students. Indeed, institutions may differ in their learning productivity, or how effectively they convert student engagement into learning outcomes (Kuh \& Hu, 2001). We examined each institution's partial correlations between student engagement measures and academic performance to determine whether students at particular institutions realized more or less academic payoff from their engagement in effective educational practices. We ranked institutions according to the strength of the associations between engagement and learning, categorizing them as high, mid-range, or low in terms of learning productivity. We then regressed each performance measure on each engagement scale, the institution's learning productivity score (converting engagement into learning outcomes), and an interaction term between engagement and learning productivity.

One drawback to using the student as the unit of analysis when estimating institutional differences is that standard errors will be biased too small, increasing the chance that coefficients will be statistically significant (Raudenbush \& Bryk, 2002). Thus, we relied on effect sizes to gauge whether institutional differences on fostering favorable engagement-performance linkages were substantively important. Should comparable data become available involving a greater number of institutions, future researchers should investigate institutional effects with multilevel modeling techniques (Raudenbush \& Bryk, 2002).

Results

\section{Relationships among RAND, GRE, GPA, and SAT}

RAND and GRE scores correlated with total SAT at .48 and .55, respectively, indicating a healthy relationship between where a student falls in the SAT distribution and where they fall in the RAND and GRE distributions. Among first-year students, RAND and GRE scores 
correlated with SAT scores at .52 and .54, respectively. Among seniors, RAND and GRE scores correlated with SAT scores at .38 and .46, respectively. The drops in both RAND-SAT (.52 to .38) and GRE-SAT (.54 to .46) correlations between the first and senior years suggest that institutions may influence student learning in the areas covered by these tests. There are, of course, other explanations, such as the effect of different grading standards across different academic majors. A curvilinear specification between RAND and SAT (but not GRE and SAT or GPA and SAT) yielded a better-fitting model than a linear one. Specifically, higher SAT scores were related to higher RAND scores only up to an SAT score of 1,434 - at which point higher SAT scores yielded slightly declining RAND scores. However, this inflection point is very high - only about 7 percent of the students tested had scores above 1,434. Finally, RAND and GRE scores correlated at .28 and .27 respectively with GPA. Controlling for SAT resulted in partial correlations of .18 and .15 for RAND-GPA and GRE-GPA, respectively.

\section{$\underline{\text { Student Engagement Scales and Academic Performance }}$}

Table 2 presents bivariate and partial correlations between student engagement scales, RAND, GRE, and GPA measures, and self-reported outcomes. As shown in Table 2, we found a number of small but statistically significant positive correlations between student engagement and scores on the RAND and GRE tests, both before and after controls were added for a host of student characteristics. Level of academic challenge, supportive campus climate, reading and writing, quality of relationships, institutional emphases on good practices, and general education gains yielded positive partial correlations with RAND of .10 or greater (Column 2). None of the 15 partial correlations with RAND scores was negative. RAND scores had somewhat higher partial correlations with engagement and self-reported outcomes (Column 4) than did GRE scores, but there were no statistically significant negative partial correlations with GRE scores. 
Reading and writing and gains in practical competence were correlated with GRE at .16 and .13, respectively.

[Insert Table 2 about here]

$\underline{\text { Student Engagement and GPA }}$

Columns 5 and 6 of Table 2 show that levels of student engagement were often positively related to GPA. Very modest but statistically significant positive partial correlations (Column 6) were found for 9 of the 11 engagement scales: level of academic challenge (.07), active and collaborative learning (.13), student-faculty interaction (.13), supportive campus climate (.08), reading and writing (.06), quality of relationships (.08), institutional emphases on good practices (.07), student-faculty interaction concerning coursework (.10), and integration of diversity into coursework (.07). In addition, significant positive correlations were noted between self-reported outcomes and GPA: general education gains (.12) and personal-social gains (.11). None of the 15 scales examined were negatively correlated with GPA. These relationships are almost certainly understated due to the lagged nature of cumulative rather than current semester GPA. Overall, the relationships between the NSSE scales, GPA, RAND, and GRE scores were comparable in strength.

In a separate analysis not shown here in tabular format, models that regressed RAND, GRE, and GPA on student characteristics, including total SAT, explained about 32\% percent of the variance in RAND, 37\% of the variance in GRE, and $13 \%$ of the variance in GPA. Using the results from these three student-level OLS regression models, we computed residuals for each student. These residual scores represented the amount of student over- or underperformance relative to predicted scores, with negative residuals denoting that a student underperformed relative to similar counterparts in the sample. We then entered the residuals for RAND, GRE, 
and GPA as dependent variables, and inserted a block of 11 student engagement measures (see Table 1) as predictors into each of the three equations. These 11 engagement measures explained 2.9, 1.3, and 3.1 percent of the variance in the residuals for RAND, GRE, and GPA, respectively. When entered into the model separately, the most powerful predictors of RAND residuals were supportive campus environment (1.8 percent), quality of relationships (1.8 percent), institutional emphases on good practices (1.0 percent), and reading and writing (.8 percent).

\section{$\underline{\text { Student Engagement Items and RAND }}$}

To probe even further into the specific forms of engagement associated with higher academic performance, we computed partial correlations between RAND and individual items on the NSSE survey for first-year students and seniors. Many of these items were included in the 15 scales presented in Table 1, but others were not. Table 3 reports only those partial correlations that achieved statistical significance for one or both classes. ${ }^{1}$ The largest positive correlations for first-year students (Column 1) were for the number of papers of fewer than 5 pages (.17), came to class having completed readings and assignments (.16), quality of relationships with faculty (.16) and administrative personnel and offices (.16), and worked harder than you thought you could to meet instructors' expectations (.14). The only significant and negative correlation between engagement and RAND for first-year students involved having serious conversations with students who were very different from you (-.14). While correlations between self-reported outcomes and RAND were generally positive, gains with respect to understanding people of other racial and ethnic backgrounds were negatively related ( -.15). Correlations for seniors (Column 2) yielded several differences. In particular, seniors appeared

\footnotetext{
${ }^{1}$ Three institutions were dropped from this subanalysis by class, because their students' classes were measured differently, i.e., a semester prior to completion of The Report rather than during the same term. However, the inclusion of these three schools did not appreciably alter the patterns reported here by class.
} 
to benefit less than first-year students from working harder, coming to class more prepared, preparing drafts of papers, writing more small papers, and having high quality relationships with collegiate employees. In contrast, seniors benefited more from working with other students on projects during class, integrating ideas from different courses, receiving high quality academic advising, and being at institutions that emphasize contact among students of different backgrounds, as well as attendance of campus events and activities.

[Insert Table 3 about here]

\section{Conditional Effects of Pre-college Ability}

We examined the linkages between student engagement, RAND, GRE, and GPA measures, and self-reported outcomes for those who scored in the lowest and highest quintiles of the SAT distribution. The lowest quintile included those who scored below 1,030 on the SAT, while the highest quintile consisted of those who scored greater than 1,330. Table 4 presents partial correlations between student engagement, academic performance, and self-reported outcomes for both the low ability and high ability groups - those who scored in the lowest quintile and highest quintile on the SAT, respectively. The results suggest that low ability students benefited more from engagement than high ability counterparts, particularly in terms of their RAND and GRE scores, and to a lesser extent, their GPA.

Column 1 displays correlations between student engagement and RAND scores for low ability students. Low ability students appeared to receive the greatest payoffs from quality of relationships (.26), a supportive campus climate (.23), integration of diversity into coursework (.20), student-faculty interaction concerning coursework (.18), and reading and writing (.18). In addition, gains in general education (.19) were significantly correlated with RAND scores for this group. In contrast, high ability students benefited considerably less than their low ability 
counterparts in that none of the 15 correlations presented in Column 2 were significant and positive, and the majority were negative. This pattern generally persists for GRE scores in Columns 3 and 4, yet the differences between low and high ability students diminishes somewhat in Columns 5 and 6 for GPA. Taken as a whole, these findings suggest that institutional interventions to boost student engagement may have the greatest payoff for those most at-risk for leaving college prematurely.

\section{[Insert Table 4 about here]}

One interpretation of the different payoffs on RAND tests for students of different abilities might be that the RAND tests tap general intellectual ability to a large degree. Highly intelligent students may simply require less effort to achieve similar academic results. This might explain the large number of modestly negative correlations for high ability students. We find some evidence to support the notion that high ability students need to expend less effort in college to do well on the RAND tests. Although the correlation between scores on the RAND tasks and the amount of reading and writing students do in college was the strongest of the 15 correlations reported for high ability students (.09), it was still less than that for low ability students (.18). In supplementary analyses not shown in Table 4, we found that low ability students had a .17 correlation between total time spent preparing/studying for class and RAND score, while high ability students sported a correlation of only .01. Similarly, working harder than you thought you could to meet instructors' expectations was correlated at .13 $(p=.09)$ with RAND score for low ability students, and only at .01 for high ability students.

Of particular interest is that the low ability group appears to benefit disproportionately from perceptions of a nurturing environment, such as a supportive campus climate and high quality relationships. Because this finding is consistent with the research on student retention 
(Pascarella \& Terenzini, 1991, 2005; Tinto, 1993), perhaps the apparent conditional effect of student ability is simply an artifact of selection processes, in that many alienated low ability students had already left institutions by this time. However, our data do not support the differential selection hypothesis. Restricting the analysis to first-year students of low ability, before the greatest risk of drop-out has occurred, continued to yield positive correlations with scores on the RAND tasks: supportive campus environment (.23) and quality of relationships (.10).

Other Conditional Effects. Earlier we reported some differential effects for first-year students and seniors (Table 3). We also tested whether engagement led to differential effects on RAND tests for women and men, whites and nonwhites, native and transfer students, and students with Greek organizational affiliations. A series of multivariate regression analyses did not reveal conditional effects for any of these measures except for level of academic challenge, which favored women. Further, we found little evidence of conditional effects by gender within particular institutions.

Institutional Differences

Klein et al. (in press) reported that students at some institutions had higher RAND and GRE scores than would be expected given the typical relationship of these scores with their SAT scores. This finding suggests that, relative to other participating institutions, certain colleges added more value than others. A final aim of our study was to determine if different institutions more effectively converted student engagement into academic performance, as measured by RAND tests. To this end, we examined the partial correlations within each institution, controlling for a curvilinear specification of SAT. Three institutions (a liberal arts college, a general liberal arts college, and a HBCU) had a large number of substantial positive associations 
between engagement and RAND performance, while the majority had few or none. Three institutions exhibited many negative relationships (two master's level universities and one doctoral extensive university). To determine whether these observed within-institution differences were statistically significant, we conducted multivariate regressions that included an interaction term between each engagement scale and a dummy variable that was coded as " 1 " if the student was from one of the three institutions identified as the most effective at promoting favorable engagement-performance linkages, and "0" if the student was at an institution that promoted the least favorable or even detrimental engagement-performance linkages. Table 5 displays interaction terms if the interaction coefficient achieved statistical significance at the .05 level.

\section{[Insert Table 5 about here]}

Table 5 shows the statistically significant differences between students at the highest and lowest schools in the learning productivity distribution. An effect size (ES) was calculated for each scale if the interaction coefficient was significant. Initially, fully-standardized coefficients were computed for the most and least effective institutions, then the absolute difference calculated to yield the boost in RAND scores (in standard deviation units) accruing to a standard deviation increase in student engagement within most versus least effective institutions. As compared institutions in the lowest learning productivity groups, institutions in the highest learning productivity group were more able to convert 8 of the 11 engagement scales into higher scores on the RAND tests:

- level of academic challenge (ES=.22)

- student-faculty interaction ( $\mathrm{ES}=.25)$

- supportive campus environment $(\mathrm{ES}=.29)$

- reading and writing ( $\mathrm{ES}=.12)$

- quality of relationships (ES=.24)

- institutional emphases on good practices ( $E S=.20)$ 
- higher-order thinking ( $\mathrm{ES}=.24$ ), and

- student-faculty interaction concerning coursework (ES=.27)

Another way to interpret these findings - given that the overall standard deviation for the RAND test was 177.55 (Table 1) - is that each standard deviation increase in level of academic challenge is linked to an additional 39 point boost $(.22 * 177.55)$. Moreover, the highest learning productivity institutions had significantly stronger relationships between RAND and studentreported outcomes (general education gains [ES=.29], personal-social gains [ES=.27], practical competence gains [ES=.20], and satisfaction [ES=.15]).

We also contrasted the top three institutions in terms of learning productivity with the eight institutions that performed near the middle of the sample, this latter set of schools included several selective liberal arts colleges, two master’s level universities, and one moderately selective doctoral degree-granting university (Table 6). As expected, we found fewer statistically significant interaction coefficients than in Table 5, even though the larger Ns at the student level (738 to 760 rather than 361 to 378) afforded additional statistical power. Even so, the institutions that appeared to perform the best were somewhat more effective at converting student-faculty interaction ( $E S=.12$ ), enriching educational experiences ( $E S=.13)$, supportive campus environment (.09), reading and writing (ES=.05), quality of relationships (ES=.08), and student-faculty interaction concerning coursework $(E S=.10)$ into greater RAND scores.

[Insert Table 6 about here]

In supplementary analyses not shown in tabular format, we found little evidence of varied institutional effectiveness for the GRE. However, this finding is based only on the six institutions that had sufficient numbers of students who completed the GRE tests. With respect to GPA, four institutions (HBCU, one selective liberal arts college, two master's level 
institutions (one public, one private) appeared to more effectively convert student engagement into higher grades.

\section{Conclusions}

On balance, the results of this study corroborate what many other researchers have found: that student engagement is linked positively to desirable learning outcomes such as critical thinking and grades. Although the relationships between engagement and academic performance were not as robust as we might hope, they were more conclusive than those reported by Ewell (2002). To the degree that student experiences, engagement, and academic performance change over the course of a collegiate career (and there is considerable evidence suggesting that this is so), the asynchrony in data collection points likely accounts for the inconclusive patterns found in the South Dakota data.

Our findings along with others (Ewell, 2002; Klein et al., in press; Pascarella \& Terenzini, 2005) underscore the fact that learning outcomes stem from a variety of sources, of which student engagement is only one. Indeed, the positive relationships between engagement and outcomes described in this paper are relatively small in magnitude. A large portion - and in some cases a majority - of the variance in key outcomes remains to be explained by yet undiscovered factors. We hope to learn more about the relationships between student engagement and learning from a Pew-sponsored National Forum on College-Level Learning project that co-administered NSSE, RAND, and the National Assessment of Adult Literacy at about 50 colleges and universities in 2003-2004.

In addition to the generally positive but relatively weak effects of engagement on critical thinking skills, the NSSE-RAND analyses point to two evocative findings. First, college students with the lowest SAT scores appeared to benefit more from student engagement than 
those with the highest SATs. While this pattern dovetails with some recent research, we cannot rule out that these findings may be in part attributable to ceiling effects or the phenomenon of regression to the mean. A future study might use multiple measures to control for student ability prior to matriculation to increase their stability. Such a strategy would decrease the probability that the very lowest or highest measures of pre-college ability were due to chance or unusual circumstances unlikely to repeat at a later measurement point.

Second, using these same data, Klein et al. (in press) suggested that certain institutions appear to add more value than others, as measured by the RAND critical thinking tests. Our analysis indicates that certain institutions more effectively convert engagement into stronger student performance as represented by RAND scores. Thus, the findings suggest that student engagement constitutes a constellation of institutional processes that may "add value" to student learning. Although this study is based on only 14 institutions, institutional differences were discernable, particularly between institutions most and least effective in converting student engagement into performance. It would be instructive to conduct intensive case studies of high performing institutions to learn what they do or have that seem to contribute to greater student learning productivity, i.e., to extend the work of Kuh, Schuh, Whitt and Associates (1991) and Kuh, Kinzie, Schuh, Whitt and Associates (2005).

In closing, it is important to note that we were able to examine the complex relationships between engagement and learning outcomes only because we were able to analyze student-level data across multiple institutions. The integration of multiple measures (SAT scores, RAND/CAE scores, grades, student engagement results from NSSE) was made possible by the cooperation of the participating colleges and different research teams. Such efforts are few and 
far between. The results of this study illustrate the insights that can accrue from such collaborative research endeavors. 


\section{References}

Astin, A.W. (1991). Assessment for excellence: The philosophy and practice of assessment and evaluation in higher education. New York: American Council on Education/ Macmillan.

Baird, L. L. (1976). Biographical and educational correlates of graduate and professional school admissions test scores. Educational and Psychological Measurement, 36(2), 415-420.

Baird, L.L. (1988). Value Added: Using student gains as yardsticks of learning. In C. Adelman (Ed.), Performance and Judgement: Essays on principles and practice in the assessment of college student learning, (205-216). Washington, D.C.: U.S. Government Printing Office.

Benjamin, R., \& Hersh, R.H. (2002). Measuring the difference that college makes. Peer Review, 4(2/3), 7-10.

Bohr, L., Pascarella, E.T., Nora, A., Zusman, B., Jacobs, M., Desler, M., \& Bulakowski, C. (1994). Cognitive effects of two-year and four-year colleges: A preliminary study. Community College Review, 22(1), 4-11.

Chun, M. (2002). Looking where the light is better: A review of the literature on assessing higher education quality. Peer Review, Winter/Spring, 16-25.

Cronbach, L.J. \& Furby, L. (1970). How we should measure “change” - or should we? Psychological Bulletin, 74(1), 68-80.

Ewell, P. T. (1984). The self-regarding institution: Information for excellence. Boulder, CO: National Center for Higher Education Management Systems

Ewell, P. T. (1988). Outcomes, assessment, and academic improvement: In search of usable knowledge. In J. C. Smart, (Ed). Higher education: Handbook of theory and research, $\underline{4}$, (53-108). New York: Agathon Press. 
Ewell, P. T. (1994). A policy guide for assessment: Making good use of the Tasks in Critical Thinking. Princeton, NJ: Educational Testing Service.

Ewell, P.T. (2002). An analysis of relationships between NSSE and selected student learning outcomes measures for seniors attending public institutions in South Dakota. Boulder, CO: National Center for Higher Education Management Systems.

Ewell, P.T., \& Jones, D.P. (1996). Indicators of "good practice" in undergraduate education: A handbook for development and implementation. Boulder, CO: National Center for Higher Education Management Systems.

Gentemann, K. M., Fletcher, J.J., Potter, D.L. (1994). Refocusing the academic program review on student learning. In M. K. Kinnick, (Ed.), Providing useful information for deans and department chairs. New Directions for Institutional Research, 84, (31-46). San Francisco: Jossey-Bass.

Halpern, D. F. (1987). Recommendations and caveats. In D. F. Halpern, (Ed.), Student outcomes assessment: What institutions stand to gain. New Directions for Higher Education 59, 109-111.

Hughes, R. \& Pace, C.R. (2003). Using NSSE to study student retention and withdrawal. Assessment Update, 15 (4), 1-2.

Jacobi, M., Astin, A. \& Ayala, F. (1987). College student outcomes assessment: A talent development perspective. ASHE-ERIC Higher Education Report No. 7. Washington, DC: Association for the Study of Higher Education.

Klein, S.P. (1996). The costs and benefits of performance testing on the bar examination. The Bar Examiner, 65,(3), 13-20. 
Klein, S.P. (2001). Rationale and plan for assessing higher education outcomes with direct constructed response measures of student skills. New York, NY: Council for Aid to Education, Higher Education Policy Series, Number 3.

Klein, S.P. (2002). Direct assessment of cumulative student learning. Peer Review, 4(2/3), 26-28.

Klein, S.P., Kuh, G.D., Chun, M., Hamilton, L., \& Shavelson, R. (in press). The search for value-added: Assessing and validating selected higher education outcomes. Research in Higher Education.

Kuh, G.D. (2001). Assessing what really matters to student learning: Inside the National Survey of Student Engagement. Change, 33(3), 10-17, 66.

Kuh, G.D. (2003). What we're learning about student engagement from NSSE. Change, 35(2), 24-32.

Kuh, G.D., Hayek, J.C., Carini, R.M., Ouimet, J.A., Gonyea, R.M., \& Kennedy, J. (2001). NSSE technical and norms report. Bloomington, IN: Indiana University Center for Postsecondary Research and Planning.

Kuh, G.D., \& Hu, S. (2001). Learning productivity at research universities. Journal of Higher Education, 72, 1-28.

Kuh, G. D., Kinzie, J., Schuh, J. H., Whitt, E. J., \& Associates (2005). Student success in college: Creating conditions that matter. San Francisco: Jossey-Bass and American Association for Higher Education.

Kuh, G.D., \& Pascarella, E.T. (2004). What does institutional selectivity tell us about educational quality? Change, $\underline{36}(5), 52-58$. 
Kuh, G.D., Schuh, J.H., Whitt, E.J., \& Associates (1991). Involving colleges: Successful approaches to fostering student learning and personal development outside the classroom. San Francisco: Jossey-Bass.

National Survey of Student Engagement (2003). Converting data into action: Expanding the boundaries of institutional improvement. Bloomington, IN: Indiana University Center for Postsecondary Research and Planning.

National Survey of Student Engagement (2004). NSSE 2004 overview. Bloomington, IN: Indiana University Center for Postsecondary Research and Planning.

Pace, C. R. (1984). Measuring the quality of college student experiences. Los Angeles: University of California, Higher Education Research Institute.

Pascarella, E.T. (2001). Identifying excellence in undergraduate education: Are we even close? Change, $\underline{33}(3), 19-23$.

Pascarella, E.T., \& Terenzini, P.T. (1991). How college affects students. San Francisco: JosseyBass.

Pascarella, E. T., \& Terenzini, P. T. (2005). $\underline{\text { How college affects students: A third decade of }}$ research (Vol. 2). San Francisco: Jossey-Bass.

Pascarella, E.T. \& Wolniak, G.C. (2004). Change or not to change: Is there a question? A response to Pike. Journal of College Student Development 45(3), 353-355.

Pascarella, E. T., Bohr, L., Nora, A., \& Terenzini, P.T. (1994). Is differential exposure to college linked to the development of critical thinking? Illinois Univ., Chicago: National Center on Postsecondary Teaching, Learning, and Assessment.

Pike, G.R. (1992). Lies, damn lies, and statistics revisited: A comparison of three methods of representing change. Research in Higher Education, $\underline{33}$ (1), 71-84. 
Pike, G.R. (2004). Lord's paradox and the assessment of change during college. Journal of College Student Development 45(3), 348-352.

Pohlmann, J.T. (1974). A description of effective college teaching in five disciplines as measured by student ratings. Research in Higher Education, 4(4), 335-346.

Ratcliff, J.L., E.A. Jones, et al. (1997). Turning results into improvement strategies. University Park: The Pennsylvania State University, National Center on Postsecondary Teaching, Learning, and Assessment.

Raudenbush, S.W. \& Bryk, A.S. (2002). Hierarchical linear models: Applications and data analysis methods $\left(2^{\text {nd }}\right.$ Ed.). Thousand Oaks, CA: Sage Publications.

Shulman, L.S. (2002). Making differences: A table of learning. Change 34(6), 36-45.

Terenzini, P. T. 1989. Assessment with open eyes: Pitfalls in studying student outcomes. $\underline{\text { Journal }}$ of Higher Education 60, 644-664.

Tinto, V. (1993). Leaving college: Rethinking the causes and cures of student attrition $\left(2^{\text {nd }}\right.$ Ed.). Chicago: University of Chicago Press.

Vandament, W.E. (1987). A state university perspective on student outcomes assessment. In D. F. Halpern, ed. Student outcomes assessment: What institutions stand to gain. New Directions for Higher Education 59, 25-28.

Winter, D.G., McClelland, D.C., \& Stewart, A.J. (1981). A new case for the liberal arts. San Francisco: Jossey-Bass. 
Table 1. Means, Standard Deviations and Descriptions for Academic Performance, Student Engagement Scales, and Self-reported Outcomes

\begin{tabular}{|c|c|c|c|c|c|}
\hline Measure & Description & Metric & Mean & SD & $\mathrm{N}$ \\
\hline \multicolumn{6}{|c|}{ Academic Performance } \\
\hline RAND Test Score & $\begin{array}{l}\text { Composite performance and } \\
\text { critical thinking score }\end{array}$ & $\begin{array}{l}\text { Standardized to SAT } \\
\text { distribution }\end{array}$ & $1,186.13$ & 177.55 & 940 \\
\hline GRE Test Score & $\begin{array}{l}\text { Composite GRE prompt } \\
\text { score }\end{array}$ & $\begin{array}{l}\text { Standardized to SAT } \\
\text { distribution }\end{array}$ & $1,120.93$ & 157.77 & 506 \\
\hline GPA & $\begin{array}{l}\text { Cumulative college grade } \\
\text { point average }\end{array}$ & $\begin{array}{l}\text { Z-scored to within school } \\
\text { distribution }\end{array}$ & .02 & .98 & 1,004 \\
\hline \multicolumn{6}{|l|}{ Student Engagement } \\
\hline $\begin{array}{l}\text { Level of academic } \\
\text { challenge }\end{array}$ & $\begin{array}{l}\text { Nature and amount of } \\
\text { academic work performed }\end{array}$ & Sum of 11 items & 18.98 & 4.33 & 1,034 \\
\hline $\begin{array}{l}\text { Active and collaborative } \\
\text { learning }\end{array}$ & $\begin{array}{l}\text { Frequency of class } \\
\text { participation and } \\
\text { collaborative learning }\end{array}$ & Sum of 7 items & 10.51 & 3.35 & 1,045 \\
\hline $\begin{array}{l}\text { Student-faculty } \\
\text { interaction }\end{array}$ & $\begin{array}{l}\text { Frequency of student } \\
\text { interactions with faculty }\end{array}$ & Sum of 6 items & 8.43 & 3.85 & 1,043 \\
\hline $\begin{array}{l}\text { Enriching educational } \\
\text { experiences }\end{array}$ & $\begin{array}{l}\text { Degree if participation in } \\
\text { educationally fruitful } \\
\text { activities }\end{array}$ & Sum of 11 items & 6.55 & 1.75 & 1,023 \\
\hline $\begin{array}{l}\text { Supportive campus } \\
\text { climate }\end{array}$ & $\begin{array}{l}\text { Degree to which the } \\
\text { institution is perceived to be } \\
\text { supportive }\end{array}$ & Sum of 6 items & 11.12 & 3.08 & 1,049 \\
\hline Reading and writing & $\begin{array}{l}\text { Amount of assigned reading } \\
\text { and writing }\end{array}$ & Sum of 3 z-scored items & -.001 & 2.25 & 1,052 \\
\hline Quality of relationships & $\begin{array}{l}\text { Quality of your } \\
\text { relationships with people at } \\
\text { your institution }\end{array}$ & Sum of 3 items & 16.21 & 2.84 & 1,054 \\
\hline
\end{tabular}

[Table 1 continued next page] 


\section{Table 1 (continued). Means, Standard Deviations and Descriptions for Academic Performance, Student Engagement Scales, and Self-reported Outcomes}

\begin{tabular}{|c|c|c|c|c|c|}
\hline Measure & Description & Metric & Mean & SD & $\mathrm{N}$ \\
\hline \multicolumn{6}{|c|}{ Student Engagement (continued) } \\
\hline $\begin{array}{l}\text { Institutional emphases on } \\
\text { good practices }\end{array}$ & $\begin{array}{l}\text { Degree institution perceived } \\
\text { to uphold good practices }\end{array}$ & Sum of 5 items & 13.15 & 3.32 & 1,047 \\
\hline Higher-order thinking & $\begin{array}{l}\text { Frequency higher-order } \\
\text { skills included in } \\
\text { coursework }\end{array}$ & Sum of 4 items & 12.43 & 2.51 & 1,052 \\
\hline $\begin{array}{l}\text { Student-faculty } \\
\text { interaction concerning } \\
\text { coursework }\end{array}$ & $\begin{array}{l}\text { Degree of interaction } \\
\text { involving coursework }\end{array}$ & Sum of 3 items & 7.94 & 1.97 & 1,051 \\
\hline $\begin{array}{l}\text { Integration of diversity } \\
\text { into coursework }\end{array}$ & $\begin{array}{l}\text { Degree coursework } \\
\text { involved diverse } \\
\text { perspectives and ideas }\end{array}$ & Sum of $5 \mathrm{z}$-scored items & -.01 & 3.39 & 1,046 \\
\hline \multicolumn{6}{|c|}{ Self-reported Outcomes } \\
\hline Gains: general education & $\begin{array}{l}\text { Self-reported gains in } \\
\text { writing, speaking, and } \\
\text { thinking critically }\end{array}$ & Sum of 4 items & 8.42 & 2.50 & 1,053 \\
\hline $\begin{array}{l}\text { Gains: personal and } \\
\text { social }\end{array}$ & $\begin{array}{l}\text { Self-reported gains related } \\
\text { to personal and community } \\
\text { issues }\end{array}$ & Sum of 7 items & 12.02 & 4.38 & 1,048 \\
\hline $\begin{array}{l}\text { Gains: practical } \\
\text { competence }\end{array}$ & $\begin{array}{l}\text { Self-reported gains related } \\
\text { to job-related skills }\end{array}$ & Sum of 4 items & 7.53 & 2.53 & 1,051 \\
\hline Satisfaction & $\begin{array}{l}\text { Degree satisfied with } \\
\text { institution }\end{array}$ & Sum of 2 items & 6.50 & 1.35 & 1,053 \\
\hline
\end{tabular}


Table 2. Correlations Between Student Engagement Scales, RAND, GRE, and GPA Measures, and Self-reported Outcomes

\begin{tabular}{|c|c|c|c|c|c|c|}
\hline Measure & $\begin{array}{c}\text { RAND } \\
\text { Bivariate } \\
\text { Correlation }\end{array}$ & $\begin{array}{c}\text { RAND } \\
\text { Partial Correlation }\end{array}$ & $\begin{array}{c}\text { GRE } \\
\text { Bivariate } \\
\text { Correlation }\end{array}$ & $\begin{array}{c}\text { GRE } \\
\text { Partial } \\
\text { Correlation }\end{array}$ & $\begin{array}{c}\text { GPA } \\
\text { Bivariate } \\
\text { Correlation }\end{array}$ & $\begin{array}{c}\text { GPA } \\
\text { Partial } \\
\text { Correlation }\end{array}$ \\
\hline \multicolumn{7}{|l|}{ Student Engagement } \\
\hline Level of academic challenge & $.11^{* * *}$ & $.10^{* *}$ & $.10^{*}$ & $.09 *$ & $.09 * *$ & $.07 *$ \\
\hline Active and collaborative learning & .02 & .02 & .06 & $.08^{*}$ & $.13^{* * *}$ & $.13^{* * *}$ \\
\hline Student-faculty interaction & .03 & .01 & .06 & .04 & $.13^{* * *}$ & $.13^{* * *}$ \\
\hline Enriching educational experiences & $.09 * *$ & .02 & $.13^{* *}$ & .07 & $.10^{* *}$ & .04 \\
\hline Supportive campus climate & $.08^{* *}$ & $.13^{* * *}$ & -.03 & -.02 & $.06^{*}$ & $.08^{* *}$ \\
\hline Reading and writing & $.12^{* * *}$ & $.10^{* * *}$ & $.16^{* * *}$ & $.16^{* * *}$ & $.08^{* *}$ & $.06^{*}$ \\
\hline Quality of relationships & $.14^{* * *}$ & $.14^{* * *}$ & .01 & -.02 & $.08^{* *}$ & $.08^{* *}$ \\
\hline Institutional emphases on good practices & .03 & $.10^{* *}$ & -.06 & -.02 & .04 & $.07 *$ \\
\hline
\end{tabular}

[Table 2 continued next page] 
Table 2 (continued). Correlations Between Student Engagement Scales, RAND, GRE, and GPA Measures, and Selfreported Outcomes

\begin{tabular}{|c|c|c|c|c|c|c|}
\hline Measure & $\begin{array}{c}\text { RAND } \\
\text { Bivariate } \\
\text { Correlation } \\
\end{array}$ & $\begin{array}{c}\text { RAND } \\
\text { Partial Correlation }\end{array}$ & $\begin{array}{c}\text { GRE } \\
\text { Bivariate } \\
\text { Correlation } \\
\end{array}$ & $\begin{array}{c}\text { GRE } \\
\text { Partial } \\
\text { Correlation } \\
\end{array}$ & $\begin{array}{c}\text { GPA } \\
\text { Bivariate } \\
\text { Correlation } \\
\end{array}$ & $\begin{array}{c}\text { GPA } \\
\text { Partial } \\
\text { Correlation }\end{array}$ \\
\hline Higher-order thinking & $.08^{*}$ & $.06^{*}$ & $.08 *$ & .07 & $.06^{*}$ & .03 \\
\hline $\begin{array}{l}\text { Student-faculty interaction concerning } \\
\text { coursework }\end{array}$ & .03 & .02 & .02 & .01 & $.11^{* * *}$ & $.10^{* * *}$ \\
\hline Integration of diversity into coursework & $.10^{* * *}$ & $.06^{*}$ & $.12^{* *}$ & $.09 *$ & $.11^{* * *}$ & $.07 *$ \\
\hline \multicolumn{7}{|l|}{ Self-reported Outcomes } \\
\hline Gains: general education & $.09 * *$ & $.10^{* * *}$ & .01 & .01 & $.11^{* * *}$ & $.12 * * *$ \\
\hline Gains: personal and social & -.02 & .04 & $-.09 *$ & -.04 & $.10^{* * *}$ & $.11^{* * *}$ \\
\hline Gains: practical competence & -.02 & .03 & $-.15^{* * *}$ & $.13^{* *}$ & -.01 & .04 \\
\hline Satisfaction & $.14^{* * *}$ & $.08^{*}$ & .07 & -.04 & $.09 * *$ & .05 \\
\hline
\end{tabular}

Note: Controls for partial correlations included total SAT score, squared SAT (RAND only), class, gender, residence, enrollment status, race/ethnicity, number of parents with a bachelor's or higher, major field, amount of unassigned reading, commute time, time spent caring for dependents, and hours worked off campus. 
Table 3. Selected Partial Correlations between Student Engagement Items, RAND Scores, and Self-reported Outcomes, First-year Students Versus Seniors

\begin{tabular}{|c|c|c|}
\hline Student Engagement Item & $\begin{array}{l}\text { Partial Correlation } \\
\text { (First-year } \\
\text { Students) }\end{array}$ & $\begin{array}{l}\text { Partial Correlation } \\
\text { (Seniors) }\end{array}$ \\
\hline Student Engagement & & \\
\hline $\begin{array}{l}\text { Prepared two or more drafts of a paper or assignment before } \\
\text { turning it in }\end{array}$ & $.11^{*}$ & -.01 \\
\hline Came to class having completed readings and assignments & $.16^{* *}$ & .01 \\
\hline Worked with other students on projects during class & -.01 & $.18^{*}$ \\
\hline $\begin{array}{l}\text { Put together ideas or concepts from different courses when } \\
\text { completing assignments or during class discussions }\end{array}$ & .09 & $.20^{*}$ \\
\hline Received prompt feedback from faculty & $.11^{*}$ & $.19 * * *$ \\
\hline $\begin{array}{l}\text { Worked harder than you thought you could to meet } \\
\text { instructors' expectations }\end{array}$ & $.14^{*}$ & -.08 \\
\hline Discussed coursework outside of class & $.14^{*}$ & .12 \\
\hline $\begin{array}{l}\text { Had serious conversations with students who were very } \\
\text { different from you (religious beliefs, political opinions, or } \\
\text { values) }\end{array}$ & $-.14^{*}$ & .07 \\
\hline Number of papers of fewer than 5 pages & $.17^{* *}$ & -.04 \\
\hline Quality of academic advising received at your institution & .04 & $.18^{*}$ \\
\hline Quality of relationships with faculty & $.16^{* *}$ & .14 \\
\hline $\begin{array}{l}\text { Quality of relationships with administrative personnel and } \\
\text { offices }\end{array}$ & $.16^{* *}$ & .03 \\
\hline
\end{tabular}

[Table 3 continued next page] 
Table 3 (continued). Selected Partial Correlations between Student Engagement
Items, RAND Scores, and Self-reported Outcomes, First-year Students Versus Seniors

Student Engagement Item

Extent to which your institution emphasized providing

support that you need to succeed academically

Extent to which your institution emphasized encouraging

contact among students of different backgrounds

Extent to which your institution emphasized attendance of campus events and activities

Self-reported Outcomes

Gains at this institution with respect to a general education

Gains at this institution with respect to writing clearly and effectively

Gains at this institution with respect to thinking critically and analytically

Gains at this institution with respect to understanding people of other racial and ethnic backgrounds

\section{Partial Correlation \\ (First-year \\ Students)}

\section{Partial Correlation \\ (Seniors)}

$.12^{*}$

$-.07$

$-.01$

${ }^{*} p<.05,{ }^{* *} p<.01,{ }^{* * *} p<.0011$-tailed test

Note: Controls included total SAT score, squared SAT, gender, residence, enrollment status, race/ethnicity, number of parents with a bachelor's degree or higher, major field, amount of unassigned reading, commute time, time spent caring for dependents, and hours worked off campus. 
Table 4. Partial Correlations between Student Engagement Scales, RAND, GRE, and GPA Measures, and Selfreported Outcomes for the Highest and Lowest Ability Students

\begin{tabular}{|c|c|c|c|c|c|c|}
\hline Measure & $\begin{array}{l}\text { Partial } \\
\text { Correlation for } \\
\text { Lowest Ability } \\
\text { RAND }\end{array}$ & $\begin{array}{l}\text { Partial } \\
\text { Correlation for } \\
\text { Highest Ability } \\
\text { RAND }\end{array}$ & $\begin{array}{c}\text { Partial Correlation } \\
\text { for Lowest Ability } \\
\text { GRE }\end{array}$ & $\begin{array}{c}\text { Partial Correlation } \\
\text { for Highest Ability } \\
\text { GRE }\end{array}$ & $\begin{array}{c}\text { Partial Correlation } \\
\text { for Lowest Ability } \\
\text { GPA }\end{array}$ & $\begin{array}{l}\text { Partial } \\
\text { Correlation for } \\
\text { Highest Ability } \\
\text { GPA }\end{array}$ \\
\hline \multicolumn{7}{|l|}{ Student Engagement } \\
\hline Level of academic challenge & .15 & .07 & $.24 * *$ & -.04 & $.18^{*}$ & .13 \\
\hline Active and collaborative learning & $.17^{*}$ & -.10 & .10 & .05 & $.17 *$ & .12 \\
\hline Student-faculty interaction & .14 & -.08 & .04 & -.02 & $.20^{* *}$ & .13 \\
\hline $\begin{array}{l}\text { Enriching educational } \\
\text { experiences }\end{array}$ & .12 & -.04 & .02 & .17 & .03 & .11 \\
\hline Supportive campus climate & $.23^{* *}$ & -.01 & .09 & -.02 & .09 & .04 \\
\hline Reading and writing & $.18^{*}$ & .09 & $.25 * *$ & -.06 & .13 & -.001 \\
\hline Quality of relationships & $.26 * * *$ & .01 & .065 & -.09 & .12 & .08 \\
\hline $\begin{array}{l}\text { Institutional emphases on good } \\
\text { practices }\end{array}$ & .14 & -.002 & .05 & .02 & .03 & .09 \\
\hline Higher-order thinking & .05 & .03 & $.22 *$ & .002 & $.16^{*}$ & .002 \\
\hline $\begin{array}{l}\text { Student-faculty interaction } \\
\text { concerning coursework }\end{array}$ & $.18^{*}$ & -.03 & .06 & -.18 & $.21^{* *}$ & .08 \\
\hline
\end{tabular}

[Table 4 continued next page] 
Table 4 (continued). Partial Correlations between Student Engagement Scales, RAND, GRE, and GPA Measures, and Self-reported Outcomes for the Highest and Lowest Ability Students

\begin{tabular}{|c|c|c|c|c|c|c|}
\hline Measure & $\begin{array}{c}\text { Partial } \\
\text { Correlation for } \\
\text { Lowest Ability } \\
\text { RAND }\end{array}$ & $\begin{array}{c}\text { Partial } \\
\text { Correlation for } \\
\text { Highest Ability } \\
\text { RAND }\end{array}$ & $\begin{array}{c}\text { Partial Correlation } \\
\text { for Lowest Ability } \\
\text { GRE }\end{array}$ & $\begin{array}{c}\text { Partial Correlation } \\
\text { for Highest Ability } \\
\text { GRE }\end{array}$ & $\begin{array}{c}\text { Partial Correlation } \\
\text { for Lowest Ability } \\
\text { GPA }\end{array}$ & $\begin{array}{c}\text { Partial } \\
\text { Correlation for } \\
\text { Highest Ability } \\
\text { GPA }\end{array}$ \\
\hline $\begin{array}{l}\text { Integration of diversity into } \\
\text { coursework }\end{array}$ & $.20^{*}$ & -.09 & .05 & .12 & $.24 * *$ & .13 \\
\hline \multicolumn{7}{|l|}{ Self-reported Outcomes } \\
\hline Gains: general education & $.19 *$ & .01 & .11 & -.06 & .14 & .09 \\
\hline Gains: personal and social & .13 & -.03 & .07 & -.08 & .13 & .12 \\
\hline Gains: practical competence & .11 & -.11 & -.002 & -.19 & $.19 * *$ & -.02 \\
\hline Satisfaction & .12 & .002 & .07 & .05 & $.20 * *$ & .09 \\
\hline
\end{tabular}

Note: Controls included class, gender, residence, enrollment status, race/ethnicity, number of parents with a bachelor's degree or higher, major field, amount of unassigned reading, commute time, time spent caring for dependents, and hours worked off campus. 
Table 5. OLS Regressions of RAND Scores on Interactions Involving Student Engagement or Self-reported Outcomes and Institutional Learning Productivity (Highest versus Lowest)

\begin{tabular}{|c|c|}
\hline Measure & Interaction Terms $^{\mathrm{a}}$ \\
\hline \multicolumn{2}{|l|}{ Student Engagement } \\
\hline Level of academic challenge & $\begin{array}{c}-3.79 \\
-160.85^{*} \\
12.04^{* * *} \\
\mathrm{ES}=.22\end{array}$ \\
\hline Active and collaborative learning & $\mathrm{NS}^{\mathrm{b}}$ \\
\hline Student-faculty interaction & $\begin{array}{l}-5.43 \\
-52.36 \\
14.17 * * * \\
\mathrm{ES}=.25\end{array}$ \\
\hline Enriching educational experiences & NS \\
\hline Supportive campus environment & $\begin{array}{c}-2.88 \\
-12059 * \\
17.07 * * \\
\text { ES }=.29\end{array}$ \\
\hline Reading and writing & $\begin{array}{c}.53 \\
64.51 \\
14.17 * \\
\mathrm{ES}=.12\end{array}$ \\
\hline Quality of relationships & $\begin{array}{c}-.66 \\
-225.66^{* *} \\
18.35^{* * *} \\
\mathrm{ES}=.24\end{array}$ \\
\hline Institutional emphases on good practices & $\begin{array}{c}-.58 \\
-53.78 \\
9.57 * \\
\mathrm{ES}=.20\end{array}$ \\
\hline Higher-order thinking & $\begin{array}{c}-8.15^{*} \\
-172.68^{*} \\
19.46^{* *} \\
\text { ES }=.24\end{array}$ \\
\hline Student-faculty interaction involving coursework & $\begin{array}{c}-12.415^{*} \\
-155.03 * \\
28.09 * * * \\
\mathrm{ES}=.27\end{array}$ \\
\hline$n$ of dive & NS \\
\hline
\end{tabular}

[Table 5 continued next page] 
Table 5 (continued). OLS Regressions of RAND Scores on Interactions Involving Student Engagement or Self-reported Outcomes and Institutional Learning Productivity (Highest versus Lowest)

Measure

Interaction Terms ${ }^{\text {a }}$

Self-reported Outcomes

$-7.60$

General education gains $\quad-93.65$

$19.83^{* *}$

$\mathrm{ES}=.29$

Personal-social gains

$-6.10^{*}$

$-43.36$

$9.80^{* *}$

$\mathrm{ES}=.27$

Practical competence gains

$-8.74$

$-36.87$

$13.27 *$

$\mathrm{ES}=.20$

Satisfaction

$-10.60$

$-105.40$

27.50*

$\mathrm{ES}=.15$

${ }^{*} \mathrm{p}<.05 * * \mathrm{p}<.010 * * * \mathrm{p}<.001$ (two-tailed) Ns ranged from 361 to 378 .

Note: Controls included total SAT score and squared SAT

${ }^{a}$ First, second, and third coefficients correspond to student engagement or self-reported outcome, institution status dummy, and multiplicative interaction, respectively

${ }^{\mathrm{b}}$ Interaction coefficient not statistically significant at the .05 level. 
Table 6. OLS Regressions of RAND Scores on Interactions Involving Student Engagement or Self-reported Outcomes and Institutional Learning Productivity (Highest versus Midrange)

\begin{tabular}{|c|c|}
\hline Measure & Interaction Terms ${ }^{\mathrm{a}}$ \\
\hline \multicolumn{2}{|l|}{ Student Engagement } \\
\hline Level of academic challenge & $\mathrm{NS}^{\mathrm{b}}$ \\
\hline Active and collaborative learning & $\mathrm{NS}^{\mathrm{b}}$ \\
\hline Student-faculty interaction & $\begin{array}{c}.55 \\
-25.26 \\
7.85 * \\
\mathrm{ES}=.12\end{array}$ \\
\hline Enriching educational experiences & $\begin{array}{c}-4.87 \\
-92.89 \\
20.10^{* *} \\
\mathrm{ES}=.13\end{array}$ \\
\hline Supportive campus environment & $\begin{array}{c}5.65^{* *} \\
-50.02 \\
8.07^{*} \\
\text { ES }=.09\end{array}$ \\
\hline Reading and writing & $\begin{array}{c}4.02 \\
35.34^{* *} \\
12.09^{*} \\
\mathrm{ES}=.05\end{array}$ \\
\hline Quality of relationships & $\begin{array}{c}6.79^{* *} \\
-129.49 \\
10.70^{*} \\
\mathrm{ES}=.08\end{array}$ \\
\hline Institutional emphases on good practices & $\mathrm{NS}^{\mathrm{b}}$ \\
\hline Higher-order thinking & $\mathrm{NS}^{\mathrm{b}}$ \\
\hline Student-faculty interaction involving coursework & $\begin{array}{c}2.52 \\
-62.34 \\
12.68^{*} \\
\text { ES }=.10\end{array}$ \\
\hline Integration of diversity into coursework & NS \\
\hline
\end{tabular}

[Table 6 continued next page] 
Table 6 (continued). OLS Regressions of RAND Scores on Interactions Involving Student Engagement or Self-reported Outcomes and Institutional Learning Productivity (Highest versus Mid-range)

\begin{tabular}{|c|c|}
\hline Measure & Interaction Terms ${ }^{a}$ \\
\hline \multicolumn{2}{|c|}{ Self-reported Outcomes } \\
\hline General education gains & $\mathrm{NS}^{\mathrm{b}}$ \\
\hline Personal-social gains & $\mathrm{NS}^{\mathrm{b}}$ \\
\hline Practical competence gains & $\mathrm{NS}^{\mathrm{b}}$ \\
\hline Satisfaction & $\mathrm{NS}^{\mathrm{b}}$ \\
\hline \multicolumn{2}{|c|}{${ }^{*} \mathrm{p}<.05^{* *} \mathrm{p}<.010 * * * \mathrm{p}<.001$ (two-tailed) Ns ranged from 738 to 760} \\
\hline \multicolumn{2}{|c|}{ Note: Controls included total SAT score and squared SAT } \\
\hline
\end{tabular}




\section{Appendix A.1: Survey Items Contributing to Student Engagement and Self-reported Outcome Scales}

I. Level of Academic Challenge (Cronbach's alpha=.70)

Item 1 . Number of hours per week spent on preparing for class (studying, reading, writing, rehearsing, and other activities related to your academic program)

2. Frequency worked harder than you thought you could to meet instructors' standards or expectations during the current school year

3. Number of assigned textbooks, books, or book-length packs of course readings during the current school year

4. Number of written papers or reports of 20 pages or more during the current school year

5. Number of written papers or reports between 5 and 19 pages during the current school year

6. Number of written papers or reports of fewer than 5 pages during the current school year

7. During the current school year, the extent coursework emphasized analyzing the basic elements of an idea, experience, or theory

8. During the current school year, the extent coursework emphasized synthesizing and organizing ideas, information, or experiences into new, more complex interpretations and relationships

9. During the current school year, the extent coursework emphasized making judgments about the value of information, arguments, or methods

10. During the current school year, the extent coursework emphasized applying theories or concepts to practical problems or in new situations

11. The extent the institution emphasized spending significant amounts of time studying and on academic work

II. Active and Collaborative Learning (Cronbach's alpha=.62)

Item 12. Frequency asked questions in class or contributed to class discussions during the current school year

13. Frequency made class presentations during the current school year

14. Frequency worked with other students on projects during class during the current school year

15. Frequency worked with classmates outside of class to prepare class assignments during the current school year

16. Frequency tutored or taught other students (paid or voluntary) during the current school year

17. Frequency participated in a community-based project as part of a regular course

18. Frequency discussed ideas from your readings or classes with others outside of class (students, family members, coworkers, etc.) during the current school year

III. Enriching Educational Experiences (Cronbach's alpha=.56)

Item 19. Frequency used an electronic medium (list-serv, chat group, Internet, etc.) to discuss or complete an assignment

20. Frequency had serious conversations with students of a different race or ethnicity than your own

21. Frequency had serious conversations with students who differed from you in terms of their religious beliefs, political opinions, or personal values

22. Have done or plan to complete a practicum, internship, field experience, co-op experience, or clinical assignments

23. Have done or plan to do community service or volunteer work

24. Have done or plan to take foreign language coursework

25. Have done or plan to study abroad

26. Have done or plan to complete an independent study or self-designed major

27. Have done or plan to complete a culmination senior experience (comprehensive exam, capstone course, thesis project, etc.)

28. Number of hours per week participated in co-curricular activities (organizations, campus publications, student government, social fraternity or sorority, intercollegiate or intramural sports, etc.)

29. The extent the institution emphasized contact among students from different economic. Social, and 
racial or ethnic backgrounds

IV. Student Interactions with Faculty Members (Cronbach's alpha=.71)

Item 30. Frequency discussed grades or assignments with an instructor during the current school year

31. Frequency talked about career plans with a faculty member or advisor during the current school year

32. Frequency discussed ideas from your readings or classes with faculty members outside of class during the current school year

33. Frequency worked with faculty members on activities other than coursework (committees, orientation, student life activities, etc.) during the current school year

34. Frequency received prompt feedback from faculty on your academic performance (written or oral) during the current school year

35. Have done or plan to work on a research project with a faculty member outside of course or program requirements

\section{Supportive Campus Environment (Cronbach's alpha=.75)}

Item 36. The extent the institution emphasized providing the support you need ed to succeed academically

37. The extent the institution emphasized helping you cope with non-academic responsibilities (work, family, etc.)

38. The extent the institution emphasized providing the support you needed to thrive socially

39. Quality of Relationships with other students at your institution

40. Quality of Relationships with faculty members at your institution

41. Quality of Relationships with administrative personnel and offices at your institution

\section{Reading and Writing (Cronbach's alpha=.61)}

Item 3. Number of assigned textbooks, books, or book-length packs of course readings

5. Number of written papers or reports between 5 and 19 pages

6. Number of written papers or reports of fewer than 5 pages

VII. Quality of Relationships (Cronbach's alpha=.60)

Item 39. Quality of Relationships with other students at your institution

40. Quality of Relationships with faculty members at your institution

41. Quality of Relationships with administrative personnel and offices at your institution

VIII. Institutional Emphases on Good Practices (Cronbach's alpha=.78)

Item 29. The extent the institution emphasized contact among students from different economic, social, and racial or ethnic backgrounds

36. The extent the institution emphasized providing the support you need ed to succeed academically

37. The extent the institution emphasized helping you cope with non-academic responsibilities (work, family, etc.)

38. The extent the institution emphasized providing the support you needed to thrive socially

42. The extent the institution emphasized the attendance of campus events and activities

IX. Higher-Order Thinking (Cronbach's alpha=.74)

Item 7. During the current school year, the extent coursework emphasized analyzing the basic elements of an idea, experience, or theory

8. During the current school year, the extent coursework emphasized synthesizing and organizing ideas, information, or experiences into new, more complex interpretations and relationships

9. During the current school year, the extent coursework emphasized making judgments about the value of information, arguments, or methods

10. During the current school year, the extent coursework emphasized applying theories or concepts to practical problems or in new situations 
X. Student-Faculty Interaction Concerning Coursework (Cronbach's alpha=.68)

Item 30. Frequency discussed grades or assignments with an instructor during the current school year

32. Frequency discussed ideas from your readings or classes with faculty members outside of class during the current school year

34. Frequency received prompt feedback from faculty on your academic performance (written or oral) during the current school year

XI. Integration of Diversity into Coursework (Cronbach's alpha $=.71$ )

Item 8. During the current school year, the extent coursework emphasized synthesizing and organizing ideas, information, or experiences into new, more complex interpretations and relationships

32. Frequency discussed ideas from your readings or classes with faculty members outside of class

43. Frequency worked on a paper or project that required integrating ideas or information from various sources

44. Frequency included diverse perspectives (different races, religions, genders, political beliefs, etc.) in class discussions

45. Frequency put together ideas or concepts from different courses when completing assignments or during class discussions

XII. Gains in General Education (Cronbach's alpha=.77)

Item 46. The extent your college experience contributed to writing clearly and effectively

47. The extent your college experience contributed to speaking clearly and effectively

48. The extent your college experience contributed to acquiring broad general education

49. The extent your college experience contributed to thinking critically and analytically

XIII. Gains in Personal and Social Development (Cronbach's alpha $=.80$ )

Item 50. The extent your college experience contributed to developing a personal code of values and ethics

51. The extent your college experience contributed to understanding people of other racial and ethnic backgrounds

52. The extent your college experience contributed to understanding yourself

53. The extent your college experience contributed to learning effectively on your own

54. The extent your college experience contributed to working effectively with others

55 . The extent your college experience contributed to acquiring broad general education

56. The extent your college experience contributed to thinking critically and analytically

XIV. Gains in Practical Competence (Cronbach's alpha=.66)

Item 57. The extent your college experience contributed to acquiring job or work-related knowledge and Skills

58. The extent your college experience contributed to analyzing quantitative problems

59. The extent your college experience contributed to using computing and information technology

60 . The extent your college experience contributed to (your) working effectively with others

$X V$. Satisfaction (Cronbach's alpha=.75)

Item 61. How would you evaluate your entire educational experience at this institution?

62. If you could start over again, would you go to the same institution you are now attending? 
Appendix A.2: Degree of Overlap Between Survey Items Contributing to Student Engagement and Self-reported Outcome Scales ${ }^{a}$

\begin{tabular}{|c|c|c|c|c|c|c|c|c|c|c|c|c|c|c|c|}
\hline \multicolumn{16}{|c|}{ SCALE } \\
\hline ITEM & I & II & III & IV & V & VI & VII & VIII & IX & $\mathrm{X}$ & XI & XII & XIII & XIV & $X V$ \\
\hline 1 & $\mathrm{x}$ & & & & & & & & & & & & & & \\
\hline 2 & $\mathrm{x}$ & & & & & & & & & & & & & & \\
\hline 3 & $\mathrm{x}$ & & & & & $x$ & & & & & & & & & \\
\hline 4 & $\mathrm{x}$ & & & & & & & & & & & & & & \\
\hline 5 & $\mathrm{x}$ & & & & & $\mathrm{x}$ & & & & & & & & & \\
\hline 6 & $\mathrm{x}$ & & & & & $x$ & & & & & & & & & \\
\hline 7 & $\mathrm{x}$ & & & & & & & & $\mathrm{x}$ & & & & & & \\
\hline 8 & $\mathrm{x}$ & & & & & & & & $\mathrm{x}$ & & $\mathrm{x}$ & & & & \\
\hline 9 & $\mathrm{x}$ & & & & & & & & $\mathrm{x}$ & & & & & & \\
\hline 10 & $x$ & & & & & & & & $\mathrm{x}$ & & & & & & \\
\hline 11 & $\mathrm{x}$ & & & & & & & & & & & & & & \\
\hline 12 & & $x$ & & & & & & & & & & & & & \\
\hline 13 & & $x$ & & & & & & & & & & & & & \\
\hline 14 & & $\mathrm{x}$ & & & & & & & & & & & & & \\
\hline 15 & & $x$ & & & & & & & & & & & & & \\
\hline 16 & & $\mathrm{x}$ & & & & & & & & & & & & & \\
\hline 17 & & $\mathrm{x}$ & & & & & & & & & & & & & \\
\hline 18 & & $x$ & & & & & & & & & & & & & \\
\hline 19 & & & $\mathrm{x}$ & & & & & & & & & & & & \\
\hline 20 & & & $\mathrm{x}$ & & & & & & & & & & & & \\
\hline 21 & & & $\mathrm{x}$ & & & & & & & & & & & & \\
\hline 22 & & & $\mathrm{x}$ & & & & & & & & & & & & \\
\hline 23 & & & $\mathrm{x}$ & & & & & & & & & & & & \\
\hline 24 & & & $\mathrm{x}$ & & & & & & & & & & & & \\
\hline 25 & & & $\mathrm{x}$ & & & & & & & & & & & & \\
\hline 26 & & & $\mathrm{x}$ & & & & & & & & & & & & \\
\hline 27 & & & $\mathrm{x}$ & & & & & & & & & & & & \\
\hline 28 & & & $\mathrm{x}$ & & & & & & & & & & & & \\
\hline 29 & & & $\mathrm{x}$ & & & & & $\mathrm{x}$ & & & & & & & \\
\hline 30 & & & & $\mathrm{x}$ & & & & & & $\mathrm{x}$ & & & & & \\
\hline 31 & & & & $\mathrm{x}$ & & & & & & & & & & & \\
\hline 32 & & & & $x$ & & & & & & $\mathrm{x}$ & $\mathrm{x}$ & & & & \\
\hline 33 & & & & $\mathrm{x}$ & & & & & & & & & & & \\
\hline 34 & & & & $\mathrm{x}$ & & & & & & $\mathrm{x}$ & & & & & \\
\hline 35 & & & & $x$ & & & & & & & & & & & \\
\hline 36 & & & & & $\mathrm{x}$ & & & $\mathrm{x}$ & & & & & & & \\
\hline 37 & & & & & $x$ & & & $\mathrm{x}$ & & & & & & & \\
\hline 38 & & & & & $\mathrm{x}$ & & & $\mathrm{x}$ & & & & & & & \\
\hline 39 & & & & & $\mathrm{x}$ & & $\mathrm{X}$ & & & & & & & & \\
\hline 40 & & & & & $x$ & & $\bar{X}$ & & & & & & & & \\
\hline 41 & & & & & $\mathrm{x}$ & & $\mathrm{X}$ & & & & & & & & \\
\hline 42 & & & & & & & & $\mathrm{x}$ & & & & & & & \\
\hline 43 & & & & & & & & & & & $\mathrm{x}$ & & & & \\
\hline 44 & & & & & & & & & & & $\mathrm{x}$ & & & & \\
\hline 45 & & & & & & & & & & & $\mathrm{x}$ & & & & \\
\hline 46 & & & & & & & & & & & & $x$ & & & \\
\hline 47 & & & & & & & & & & & & $\mathrm{x}$ & & & \\
\hline 48 & & & & & & & & & & & & $\mathrm{x}$ & & & \\
\hline 49 & & & & & & & & & & & & $\mathrm{x}$ & & & \\
\hline 50 & & & & & & & & & & & & & $\mathrm{x}$ & & \\
\hline 51 & & & & & & & & & & & & & $\mathrm{x}$ & & \\
\hline 52 & & & & & & & & & & & & & $\mathrm{x}$ & & \\
\hline 53 & & & & & & & & & & & & & $\mathrm{x}$ & & \\
\hline 54 & & & & & & & & & & & & & $\mathrm{x}$ & & \\
\hline 55 & & & & & & & & & & & & & $\mathrm{x}$ & & \\
\hline 56 & & & & & & & & & & & & & $\mathrm{x}$ & & \\
\hline 57 & & & & & & & & & & & & & & $\mathrm{x}$ & \\
\hline 58 & & & & & & & & & & & & & & $\mathrm{x}$ & \\
\hline 59 & & & & & & & & & & & & & & $x$ & \\
\hline 60 & & & & & & & & & & & & & & $\mathrm{x}$ & \\
\hline 61 & & & & & & & & & & & & & & & $\mathrm{x}$ \\
\hline 62 & & & & & & & & & & & & & & & $\mathrm{x}$ \\
\hline
\end{tabular}

${ }^{\mathrm{a}}$ See Appendix A.1 for the denotation of Item and Scale numbers. 